\title{
Visions of the Global: the Classical and the Eclectic in Colonial East African Architecture
}

\section{Sarah Longair}

\section{(2) OpenEdition}

\section{Journals}

Electronic version

URL: https://journals.openedition.org/eastafrica/327

DOI: $10.4000 /$ eastafrica.327

ISSN: 2790-1076

\section{Publisher}

IFRA - Institut Français de Recherche en Afrique

\section{Printed version}

Date of publication: 1 March 2016

Number of pages: 161-178

ISSN: 2071-7245

\section{Electronic reference}

Sarah Longair, "Visions of the Global: the Classical and the Eclectic in Colonial East African Architecture", Les Cahiers d'Afrique de l'Est / The East African Review [Online], 51 | 2016, Online since 07 May 2019, connection on 09 December 2021. URL: http://journals.openedition.org/eastafrica/327 ; DOI: https://doi.org/10.4000/eastafrica.327 


\section{Visions of the Global: the Classical and the Eclectic in Colonial East African}

Architecture $^{1}$

Sarah Longair

Zanzibar was a British Protectorate for over seventy years, during which time many largescale building projects were completed yet only rarely was a wholly classical style used. This is in some respects surprising: classical elements have long been recognised internationally as symbolic of state power. A rich and burgeoning body of scholarship explores the diverse ways in which colonial governments and architects employed the classical style across the British Empire, paying careful attention to local and imperial influences upon building design. The use of the classical is of course not limited to imperial governments: as Carla Bocchetti has noted, neoclassicism is 'a global product' that can offer 'a legitimizing language to construct identity based on ideas of progress and cosmopolitanism'. ${ }^{2}$ Yet in early colonial Zanzibar (1890-1925 for the purposes of this essay), its use was the exception rather than the rule - the Post Office building (completed 1907) most explicitly using classical forms.

The overall preference for an eclectic style of building reflects the nature of British colonial rule in Zanzibar. With reference to precedents in India and elsewhere in Africa, this essay will discuss the use of the classical in the early colonial urban landscape. Architecture in East Africa is a vital source through which to understand the particular nature of colonial entanglement in the region. As Demissie writes, 'colonial architecture and urbanism played pivotal roles in shaping the spatial and social structures of African cities during the nineteenth and twentieth centuries'. ${ }^{3}$

This article will discuss how the use of particular forms and styles, or indeed the rejection of them, offers new perspectives of global connections in the British East African territories. Buildings constructed within the British Empire need to be understood within the longer history of British architecture from which they have often been excluded. ${ }^{4}$ But they are also important material evidence for historians when tracing imperial networks and influences. Chronologically, East Africa's incorporation into empire and its rapid development, influenced by political and architectural models from earlier imperial expansion, make this region particularly significant.

\footnotetext{
${ }^{1}$ My thanks to Carla Bocchetti, the anonymous readers and colleagues at IFRA for their constructive comments in developing this article. It draws on archival research undertaken in 2009-12 supported by a small grant from the British Institute of East Africa and a doctoral studentship from the UK Arts and Humanities Research Council.

${ }^{2}$ Carla Bocchetti, Neoclassical Pompai in Early Twentieth-Century Cartagena de Indias Colombia. In Buen Gusto and Classicism in the Visual Cultures of Latin America, 1780-1910, eds. Paul B. Niell and Stacie G. Widdifield (Albuquerque, NM: University of New Mexico Press, 2013) p.72.

See also Carla Bocchetti, “Antiquity and Global History,” Unpublished paper, IFRA, Nairobi, 2015.

${ }^{3}$ Fassil Demissie, Imperial Legacies and Postcolonial Predicaments: An Introduction. In Postcolonial African Cities: Imperial Legacies and Postcolonial Predicaments, ed. Fassil Demissie (London: Routledge, 2007) p.1.

${ }^{4}$ Alex G. Bremner, "Nation and Empire in the Government Architecture of Mid-Victorian London: The Foreign and India Office Reconsidered”, The Historical Journal 48, no. 3 (2005): pp xii-xiii.
} 
In order to analyse the implications and use of classical architecture in East Africa, this article focuses upon the buildings of John Sinclair, the administrator-architect who from the early 1900 s to 1923 designed the majority of Zanzibar's government buildings and several private projects, leaving an unmistakeable and enduring influence on Zanzibar's townscape. ${ }^{5}$ Sinclair's work is most notable for the development of his own version of an eclectic 'Saracenic' style, deemed appropriate for Zanzibar. Popular in the late nineteenth and early twentieth century, eclecticism in the empire allowed references to be made to precolonial building traditions, creating a sense of continuity with local tradition and rulers of the past. ${ }^{6}$ Sinclair's most celebrated and prominent buildings - the British Residency (completed 1903, then known as the Regency building) and the Peace Memorial Museum (opened 1925) - incorporate numerous local and international stylistic references. In contrast, the final building he worked on for East Africa, completed after he resigned as a British Resident in Zanzibar in 1923, was the McMillan Library in Nairobi in a purely classical style.

This article argues that we should not see this as Sinclair's 'progression' towards a classical form, but rather use his buildings to illuminate the many competing factors which impinged upon the decisions made by architects in the colonies, determined by environment, urban space and ideas about local peoples, as well as formal stylistic concerns. Attention to the compromises and contingencies inherent in colonial architecture in tropical regions also allows us to move beyond Orientalist readings of such buildings. ${ }^{7}$ Recent scholarship on neoclassicism in the Indian Ocean region signals new developments in the ways in which use of this global style during the colonial era is being re-evaluate. ${ }^{8}$ The language of colonial architecture is ungrammatical to many architectural purists yet acts as a revealing historical source. As Mordaunt-Crook reminds us, by the early twentieth century the dilemma for architects was which, of the many styles available, was appropriate for each function to create the correct cultural and political associations. ${ }^{9}$

Alongside these aspects of style and association in architecture, it is worth noting that fundamental elements of architectural history, such as tracing influences and flows of information and knowledge beyond local, regional or national boundaries, also underpin global history. ${ }^{10}$ Moves have been made by Ching, Jarzombek and Prakash with their major volume A Global History of Architecture to address the confluence of architectural

\footnotetext{
${ }^{5}$ Dean Sinclair, “Memorials More Enduring Than Bronze': J. H. Sinclair and the Making of Zanzibar Stone Town”, African Geographical Review 28 (December 2009): 71-97.

Sarah Longair, Cracks in the Dome: Fractured Histories of Empire in the Zanzibar Museum, 1897-1964 (Farnham, Surrey: Ashgate, 2015) pp. 69-110.

${ }^{6}$ Gwendolyn Wright, Tradition in the Service of Modernity: Architecture and Urbanism in French Colonial Policy, $1900-$ 1930. In Tensions of Empire: Colonial Cultures in a Bourgeois World, ed. Frederick Cooper and Ann Laura Stoler (Berkeley, CA: University of California Press, 1997) pp.322-45.

${ }^{7}$ Mark Crinson, Empire Building: Orientalism and Victorian Architecture (London: Routledge, 1996) pp. 7-8.

${ }^{8}$ Musée des arts décoratifs de l'Océan Indien. Neoclassicism in the European Colonies of the 18th \& 19th Centuries:

International Symposium Proceedings. Réunion Island, 2011.http://madoi.re/attachments/evenements/actes-neoclassicisme/ Proceedings $\% 20$ of $\% 20$ the $\% 20$ Neoclassicism\%20symposium\%20-\%20MADOI.pdf.

${ }^{9}$ Mordaunt J. Crook. The Dilemma of Style: Architectural Ideas from the Picturesque to the Post-Modern (London: John Murray, 1989) p.11.

${ }^{10}$ Maxine Berg, ed., Writing the History of the Global: Challenges for the 21st Century (Oxford: Oxford University Press 162 for The British Academy, 2013).
} 
history and global history. ${ }^{11}$ This work proposes not simply to expand the range of cultural architectural traditions which are commonly studied to reflect a global vision, but also to highlight connections beyond the local and to study how information and ideas travelled. Central to their project is the recognition that every local study is embedded within a range of cultural networks and political and economic forces which influence the outcome of building projects. ${ }^{12}$ By tracing the webs of influence upon architects and the impact they attempted to make with their designs, this article demonstrates how productive architectural evidence can be for global history.

A further factor of interest, which comes to light in these case studies, is how scholars deal with the 'amateur' in the colonial world. Depending on the size of the territory, colonial officers were expected to undertake a wide variety of tasks. Some did these willingly as hobbies and pastimes (such as collecting natural history or botanical specimens), but others were expected as part of their official duties to work in areas in which they had no qualifications or basic training. Such was the reality of working in small colonial territories. Isolation from the metropole could have several effects: lack of communication or experience of modern developments; responses to local and regional influences; and maintenance of values which might be considered outmoded in the imperial centre. Sinclair is a fascinating example in this respect. He undertook a few years of architectural training in London but would have been, by his own admission, unlikely to rise to a stellar position in the architectural profession in London. Yet he was given free reign and authority over design in Zanzibar for the first quarter of the twentieth century.

When analysing the works of unqualified architects such as Sinclair, we must therefore remain mindful of the fact that his motivations might be more instinctive than theoretical or structural. Until the 1920s when a professional architect, P. W. Harris, was employed in the Public Works Department, Sinclair's voice in architectural matters was authoritative. Being 'qualified' to undertake the role therefore depended upon the network in which he operated. In the East African arena, Sinclair's initial architectural training in the London offices of a major architect was sufficient to make him at times the best-qualified person in the region. Garth Myers ${ }^{13}$ highlights the significance of subsequent 'amateur' figures, such as Eric Dutton and Ajit Singh Hoogan, the latter of whom ultimately gained his qualifications, and both of whom worked across East Africa, including Zanzibar and Nairobi.

Hoogan in particular was a highly accomplished designer who effectively blended local, regional and global styles in a coherent architectural vision. ${ }^{14}$ While Sinclair's buildings may lack the elegance of Hoogan's work, they were influential. For example, Dutton invited Sinclair back to Zanzibar in 1946 to assist with designs for the new Mnazi Mmoja

\footnotetext{
${ }^{11}$ Francis D. K. Ching, Marc M. Jarzombek and Vikramaditya Pakrash, A Global History of Architecture (John Wiley \& Sons, 2011).

${ }^{12}$ Ibid, p. xi.

${ }^{13}$ Garth Myers, Verandahs of Power: Colonialism and Space in Urban Africa (Syracuse, NY: Syracuse University Press, 2002).

${ }^{14}$ Ibid, p. 26
} 
hospital and the new town hall in Ng'ambo. ${ }^{15}$ As Chief Secretary from 1942-52, Dutton wielded great influence over the urban development of Zanzibar as Sinclair had in the first quarter of the twentieth century. Here I seek to shed light on these early British architectural endeavours in colonial East Africa through an analysis of Sinclair's eclecticism and selective use of classicism.

Tantalisingly, Sinclair's memoirs (now in the Royal Commonwealth Society Library in Cambridge) include few references to the motivations for his building designs. This article therefore focuses upon the buildings themselves and upon newspaper accounts and government papers, where available, which refer to these edifices. Rather than give full, detailed architectural and historical examinations of individual buildings (although each merits attention), it takes the extant buildings of a single architect and supporting written material to consider the way in an international architectural style, such as the classical, was put to use in the new East African colonial territories. As a study of global history, it will discuss how different overlapping networks conveyed architectural influences and ideas between regions, and connected individuals and communities within colonial East Africa.

\section{The classical in the Colonial World}

During the mid- to late-nineteenth century, lively debates took place in Victorian architectural circles around the possible forms for new buildings in the expanding British Empire. The burgeoning demands of imperial rule required not only government facilities and law courts but also railway termini, post offices, churches and schools. In the first half of the nineteenth century, classical was the preferred style, in particular for official residences, establishing the British alongside the great Greek and Roman empires of antiquity, and the architectural elements themselves embodying ideas about order, authority and proportion. Thomas Metcalf's ground-breaking An Imperial Vision: Indian Architecture and Britain's $R a j{ }^{16}$ demonstrated the ideological and practical reasons behind the development of NeoSaracenic architecture in India, a style which fused local and international influences, which some believed more appropriate for British rule over an Indian population. Metcalf makes clear, however, that there was no linear movement towards a hybrid Neo-Saracenic style away from the classical. Classical styles in the empire in fact enjoyed a significant revival in the early twentieth century, through the works of Herbert Baker and Edwin Lutyens. Similarly, in London, inconsistency in the development of a national or imperial style ensured that the Gothic revival, embraced in Augustus Pugin's Houses of Parliament, was not universally supported. By 1900, Whitehall largely consisted of a series of classical government buildings. ${ }^{17}$ For certain particular types of building, however, Gothic revival styles prevailed. Through an empire-wide study of ecclesiastical architecture, Bremner ${ }^{18}$ explores how the Gothic was used within the expansion of the Anglican Church, paying

\footnotetext{
${ }^{15}$ Longair, Cracks in the Dome, p. 106

${ }^{16}$ Thomas R. Metcalf, An Imperial Vision: Indian Architecture and Britain's Raj (London: Faber, 1989).

${ }^{17}$ Michael Port, Imperial London: Civil Government Building in London 1850-1915 (New Haven; London: Yale University Press, 1995) p. 1, 274.

${ }^{18}$ Alex G. Bremner, Imperial Gothic: Religious Architecture and High Anglican Culture in the British Empire, C. 1840-70

164 (New Haven: Yale University Press, 2013).
} 
close attention to the local circumstances which governed the eventual form of individual churches within a global religious network.

The preference for classical architecture for European governments is rooted in the basic principles and virtues of this style - in particular that of proportion and order as well as its association with the ancient civilisations and empires of Greece and Rome. The orders of architecture, as outlined by Vitruvius and taken up and reinvigorated by Palladio in the sixteenth century, comprising series of elements with particular proportions and characteristics, had by the nineteenth century clear associations with the authority of 'civilised' nations supported by state power. Bremner uses the debates surrounding the construction of London's Foreign and India Office to move beyond a simple 'classical versus Gothic' debate to demonstrate how closely architecture was influenced by ideas about British identity, 'national/imperial self-perception' and 'the expression of national prestige' in the mid-nineteenth century. ${ }^{19}$ These debates centred on the 'appropriateness' of style which is of particular concern when transposed to the varied territories of empire. ${ }^{20}$ Implicit in this was the comparison between the British Empire and those of Greece and Rome - an association forged in the classroom through classical education, a key influence upon many of Britain's leading and influential politicians and intellectuals.

Such debates were then played out across the empire with varying responses to indigenous architecture, the environment, the type of imperial governance, and cultural and racial perceptions of inhabitants. Classical forms, for example, were eagerly taken up in the American colonies and the West Indies, where what became known as 'American Colonial' made clear reference to Palladian villas on the mainland of the Veneto and embedded an image of settler power and, critically, land ownership. ${ }^{21}$ The use of the classical across the European empires created a global architectural language understood by the many mobile people who lived across imperial territories. These intra-imperial communities did not just consist of European administrators, soldiers and sailors, but also indentured labourers, merchants, convicts and settlers. They too brought associations from elsewhere, and in the case of convicts and labourers, might well have actually constructed the buildings. As was clear in India, however, other styles and forms circulated. The convergence of the classical and other architectural styles in Zanzibar in the early twentieth century demonstrates how far local circumstances and networks determined the choice of style (for other examples in the informal empire. ${ }^{22}$

\section{Sinclair's Training and Early Work in Mombasa}

John Sinclair arrived in East Africa in the 1890s as an auditor for the Uganda Railway. Previously he had trained to be an architect, first in a practice near his home on the Isle of

\footnotetext{
${ }^{19}$ Bremner, Imperial Gothic pp.703-705. The chronology in particular is important for Bremner here: the mid-nineteenth century has at times been considered by historians as an 'anti-imperialist' age in contrast with the more jingoistic sentiments evident in the latter decades of the century.

${ }^{20}$ Mordaunt, The Dilemma of Style, p. 15-17.

${ }^{21}$ Robert Tavernor, Palladio and Palladianism (London: Thames and Hudson, 1991) pp. 181-209.

Jan Morris, In Quest of the Imperial Style. In Architecture of the British Empire, ed. Jan Morris and Robert Fermor-Hesketh (London: Weidenfeld and Nicolson, 1986) p. 20.

${ }^{22}$ Crinson, Empire Building.
} 
Wight, and then in the offices of John Loughborough Pearson, a revered late-nineteenth century London-based architect. ${ }^{23}$ Pearson was known to be a champion of the Gothic revival and much of this work was ecclesiastical, most famously in the design for Truro Cathedral. According to his memoirs, Sinclair enjoyed his work as a trainee architect, and recorded his interest in the work of Richard Norman Shaw, an architect renowned for his eclectic style of design. By 1900, eclecticism, in spite of its critics, was a widely recognised style which fused elements from different forms and styles. The skill of Shaw and others adopting this approach lay in cohering these elements in an accomplished and elegant manner, as opposed to creating an architectural jumble. Sinclair, enthused by these modern architects but 'having little hope of emulating Sir Christopher Wren'24, decided to take a job in the newly established Audit Office for the Uganda Railway.

On his arrival in Mombasa, the local authorities soon discovered Sinclair had some architectural training. He designed various plain buildings for the new law courts but more influential in the development of his eclectic architectural style was his involvement in the design for Mombasa Cathedral. Although the extent of Sinclair's contribution to the design cannot be precisely determined from available sources, the incorporation of narrow trifoliate arches in groups of three, the narrowing rows of arches on ascending registers on the transepts, and the crenellations were arrangements and features which he would continue to use. His assessment in his memoirs was brief but revealing - he hoped it would be 'sufficiently Arabesque' and not be out of place in 'an old Arab town'. ${ }^{25}$ This somewhat loose use of the term Arabesque (purely as an adjective related to the Arab community rather than the more specific reference to the flowing lines present in Islamic art and architecture) nonetheless is a clear indication that Sinclair viewed Swahili coast architecture as predominantly Arabian in style. He blended a Christian cathedral with a large dome into the cityscape through ornamentation, crenellations - visible on the many Arab palaces in Mombasa - and details such as polylobed arches. Sinclair's personal experience with the world beyond Europe was at this point confined to his journey to Mombasa via the Suez Canal. ${ }^{26}$ However, it is possible that he came into contact with the work of Owen Jones and other 'manuals' of international styles, as well as the debates in The Builder and the Journal of the Royal Institute of British Architects about which forms of architecture were suitable in India and other colonies. Sinclair's direct experience of the Arab world was formed during his residence in East Africa, a cultural contact zone between Arabia, south Asia and the African continent for millennia.

\section{Sinclair's Zanzibar Buildings}

Sinclair took up the position of Vice Consul in Zanzibar in 1899. Within a few years, the First Minister (and Regent during the minority of Sultan Ali bin Hamud), Alexander Rogers commissioned him to build a magnificent new palace (Figures 1 and 2). This was the first

\footnotetext{
${ }^{23}$ Longair, Cracks in the Dome, pp. 72-76.

${ }^{24}$ John Houston Sinclair, 'Senex Africanus: Reminiscences of Early Days in England, Kenya, Zanzibar and Tangier', n.d. [c. 1955] (Cambridge University Library: Royal Commonwealth Society Library, RCMS 180) p. 12.

${ }^{25}$ Ibid, p. 51.

${ }^{26}$ Crinson, Empire Building, p.4 has discussed how British architects in the Near East had limited direct experience but 166 their ideas about 'the East' were formed in the imagination.
} 
occasion on which Sinclair was given the freedom to develop his own architectural style. Although highly eclectic, he incorporated a greater range of classical features here than in any of his later 'Saracenic' buildings. Its function is critical to its design. Zanzibar had become a British Protectorate in 1890, with the Sultan's Government led by a British First Minister and with other Europeans in leading positions. The British Agent and Consul General dominated foreign affairs and was answerable to the Foreign Office in London. This form of 'dual government' had functioned well during the 1890s when General Sir William Lloyd Mathews - long-term resident in the service of the Sultan since the 1870s - had acted as First Minister. Mathews's death in 1900 and, soon after, the death of Sultan Hamud led to the appointment of Rogers and the commencement of the regency of the young Sultan. A new era of government therefore began. Rogers chose to usher in his appointment with the commission of his residence - the first major ceremonial building to be constructed since Sultan Barghash's Beit al-Ajaib (House of Wonders) in the 1870 s and 80s. ${ }^{27}$ It represented an opportunity for Sinclair to define a new architectural identity for the British Protectorate. In a society led by an Arab ruling minority, an elite which included Europeans and South Asians, and a majority Swahili population, there were a range of potential influences and audiences. British responses to Zanzibar's architecture, inspired by the assessment of Richard Burton in the 1850s, in general lamented how regular its buildings were compared to typical 'eastern cities'. As Burton wrote ${ }^{28}$ :

A Puritanical plainness characterized the scene - cathedrals without the graceful minarets of Jeddah, mosques without the cloisters of Cairo, turrets without the domes and monuments of Syria; and the straight sky-line was unrelieved except by a few straggling palms (Burton 1872, 32).

The Ibathi sect of Islam, to which most of its inhabitants adhered, advocated austere mosque design. The palaces of Arab merchants on Zanzibar's seafront likewise lacked ornamentation. Sultan Barghash's Beit al-Ajaib, built in the 1870s-80s, with its Indian-inspired verandahs and high clock tower broke with tradition in this respect. ${ }^{29}$ As British Resident in the late 1910s, Frederick Pearce wrote ${ }^{30}$,

Built as it is on a low promontory, jutting out into the bluest of seas, it has every advantage of site. But alas! One looks in vain for the domes and minarets and clustered pinnacles which an eastern city should possess.

These prevailing ideas about the existing cultural heritage informed the British vision for Zanzibar town, and the resultant buildings can be viewed as an attempt to enhance the 'eastern' quality of the townscape.

\footnotetext{
${ }^{27}$ This design was heavily influenced by Sultan Barghash's exile in India before becoming Sultan in 1870. It is important to note that Indian architects and builders were influential in diversifying Zanzibar's architecture in the nineteenth century.

${ }^{28}$ Richard Francis Burton, Zanzibar: City, Island and Coast (London: Tinsley Bros, 1872) p.32.

${ }^{29}$ Abdul Sheriff, Zanzibar Stone Town: An Architectural Exploration (Zanzibar: Gallery Publications, 2008) p. 78.

${ }^{30}$ F.B. Pearce, Zanzibar: the Island Metropolis of Eastern Africa (London:T.Fisher Unwin, 1920) p.146.
} 

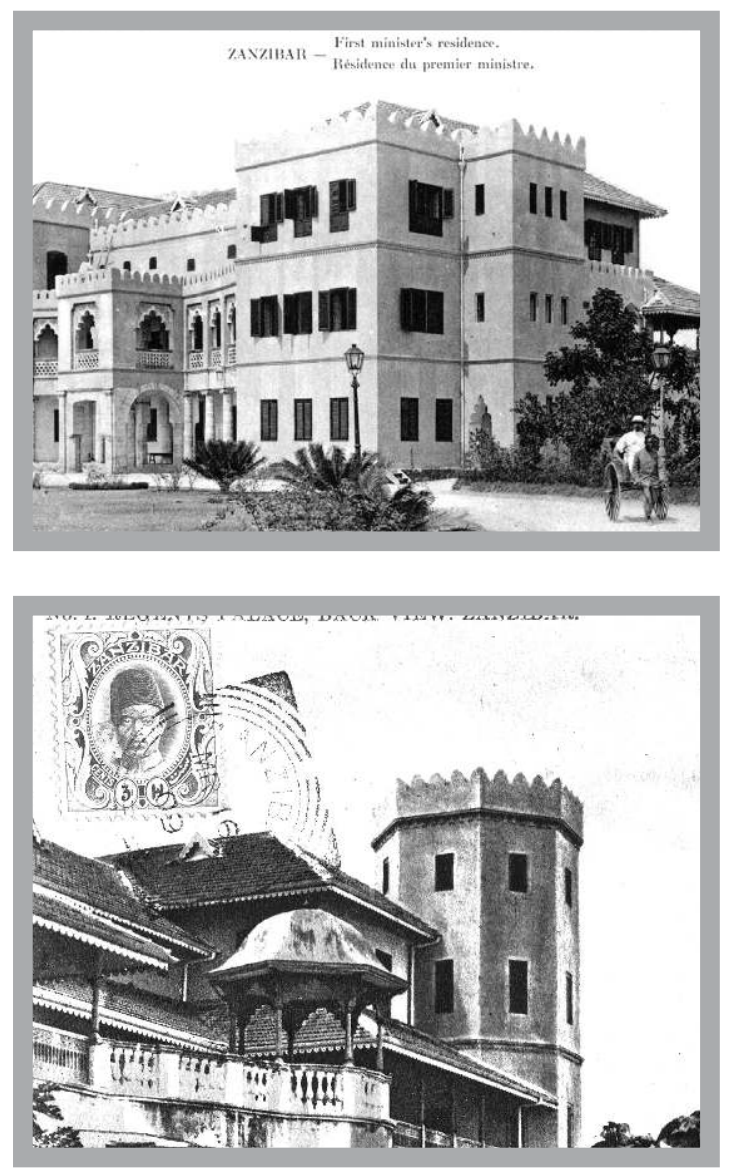

Fig 1. Postcard of the east (town-facing) façade of the Residence in Zanzibar built for Alexander Rogers, Regent and First Minister, completed 1903, designed by John Sinclair. Courtesy of Terrence Royer, www.zanzibarhistory.org
Fig 2. References cited: Postcard of the west (seaward) façade of the Residence in Zanzibar built for Alexander Rogers, Regent and First Minister, completed 1903, designed by John Sinclair. Courtesy of Terrence Royer, www.zanzibarhistory.org

While Sinclair does not record communications with Rogers about stylistic preferences for the building in his memoirs, it is likely that details of the commission may be found in the Secretariat files of the Zanzibar National Archives. From the evidence accessible for this article, it is perhaps significant that Rogers had served on the East African coast at Lamu where he inhabited a former Arab palace. Photographs reveal he had a large collection of local furniture, including several viti vya enzi (Swahili chairs of power) and Indian blackwood furniture. He arranged his substantial collection of ceramics in a typically Swahili local format, in what Prita Meier has described as Swahili 'logics of display'. ${ }^{31}$ It is possible therefore that Rogers, who had been born in India and spent his career around the Indian Ocean rim with only his schooling taking place in England, expressed his preference for a palace that reflected local prestigious buildings.

Arguably, for an administrator with fewer connections to the Indian Ocean and East Africa, the commission for a British ceremonial building might have taken a purely classical style; but the combination of Rogers as an Indian Ocean careerist and Sinclair with his recent experience in Mombasa and professed admiration of eclecticism in architecture, may have determined the final design which drew on a wide variety of local influences. 
The plan of the building incorporates two long façades - the eastern side facing the garden and the drive along which guests would arrive, and the western side with a seaward aspect. From images in Rogers's album it is clear that the eastward front lawn of the palace was regularly used for receptions and parties; it therefore acted as a backdrop to the very regular ceremony that was a feature of Zanzibar's colonial society ${ }^{32}$ (Figure 1). While features were drawn from various traditions, the symmetry and proportions of this frontage are classical. Sinclair used polylobed arches rhythmically in the central part of the façade, including the first-floor balcony. ${ }^{33}$ An Ionic colonnade around the entrance supports this arched balcony. This created a formal and convenient reception area using the more elegant of the orders, but one which does not compete with the more ornamental first floor. The whole is surmounted by crenellations typical of Swahili and Arab architecture along the East African coast. Windows across the side wings have no decorative treatment.

The western, seaward side of the building is also symmetrical but becomes more Picturesque in its composition, with the inclusion of a turret reminiscent of a British castle at the southern end (Figure 2). A Tuscan colonnade supports a first floor verandah, which in its central treatment has a classical balustrade and an Indian-style canopied pergola.

Photographs of the interior indicate that on the ground floor, Ionic columns were used structurally in combination with a stairwell decorated with pierced geometric patterns. Throughout, therefore, these stylistic features were entirely blended - employing classical forms for structural reasons. Verandahs were practical for creating spaces with breeze and airflow, which had become a norm in the colonial tropics worldwide. Given the verandah's associations with colonial India and patchwork application of references to Zanzibar and the Arab world, the classical here was the element of the building that represented British influence. The town-facing east façade, with its classical composition and symmetry and incorporation of polylobed arches simultaneously gives a sense of authority and response to the locality. The westward façade, towards the sea, is more Picturesque. One of the criticisms levelled by proponents of the Gothic revival was that classicism had stifled the development of architecture and created a monotonous sequence of porticoed structures. Laying aside any judgements about Sinclair's adeptness as an architect, the design was certainly novel and original.

\footnotetext{
${ }^{32}$ Longair, Cracks in the Dome, p. 46.

${ }^{33}$ This style of arch had precedents in stepped structural arches in local mosques (Abdul Sheriff, Verandahs of Power, p. 66) and more recently on the minaret of the Indian-inspired Hujjatul Islam mosque (completed 1894). Muslim elite women observed receptions on the lawn from this balcony while respecting purdah restrictions.
} 


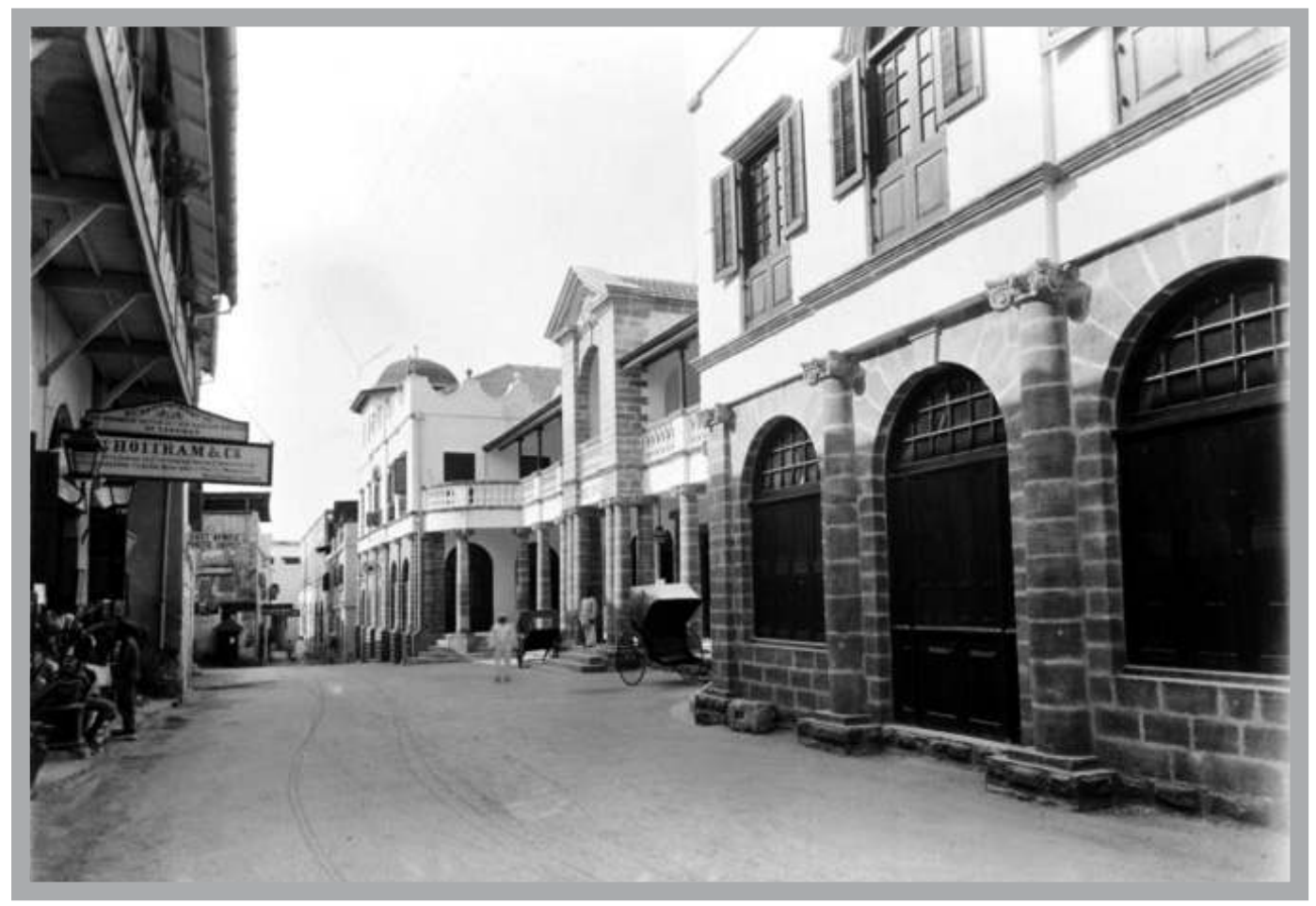

Fig 3. Northern wing of the Post Office in Zanzibar, completed 1907, designed by John Sinclair.

Rogers's residence was inaugurated in 1903. Four years later, Sinclair's second major design for Zanzibar was opened - the Post Office building (Figures 3). As noted earlier, there was a tradition in Britain for municipal buildings to be constructed in the classical style. In the case of the new Post Office for Zanzibar, Sinclair had a constricted urban site, unlike the open space which allowed him greater freedom for the Regent's residence. The Post Office was to be built in the heart of Zanzibar town, on a pre-existing, awkward, sloping corner site nestled amongst Arab and Indian palaces. Sinclair chose to use classical features for this building but further demonstrated his freedom to experiment and incorporate structures more suitable for the environment, such as verandahs. Once again he created an idiosyncratic version that did not conform to general rules. Although it lies on a slope, the street frontage is broadly symmetrical in a tripartite classical composition with an ogee-domed turret at the lower end, adding a Picturesque element (Figure 3). In the centre, a curved Ionic colonnade and a first-floor balcony flank a central feature with plainer wings on either side. On each wing, Ionic half columns and pilasters separate a series of arched windows at ground level. The first floor of each wing has an arched window with two rectangular ones on either side, all with shutters. As in India and the Caribbean, the addition of shutters to classical forms instantly has the effect of creating a 'tropical classicism'. The façade is decorated at roof level with a curvaceous parapet wall and ball finials. In the central archway, Sinclair rejected the conventional hierarchy of the orders, by placing plain Tuscan pilasters above double Ionic columns. The verandah itself has a pitched roof with very slender wooden Ionic square piers. 
When originally constructed, the stonework was left exposed and unpainted (although now it is whitewashed). ${ }^{34}$ The traditional building material in Zanzibar is a mortar made from coral - therefore this conspicuous stonework (rusticated at ground level) was a novelty in Zanzibar and created a sense of solidity and strength. Although Sinclair employed classical features more consistently on this building, he applied them in such a way as to diverge wildly from the established conventions of classical architecture. On nearing its completion, the Zanzibar Gazette of 1907 described it simply as 'an additional piece of architecture'. Later in the same paragraph, the writer described extensively and admiringly the new house of prayer for the Ismaili Jamat Khana: 'without exception the finest building in Zanzibar' with its 'massive stone pillars and exquisitely carved capitals' (Zanzibar Gazette, 24 April 1907:2). Unlike the Post Office, which received only passing notice, Sinclair's later 'Saracenic' buildings for the new law courts were described in detail in the Gazette and drew admiring commentary (Zanzibar Gazette, 6 May1908:3). The author of these articles is likely to have been Dr Alfred Henry Spurrier, Medical Officer and editor of the Gazette. He was regarded locally as an authority on scientific and cultural matters, later becoming the first curator of Zanzibar's new museum in the early 1920s. Although the opinions expressed in the Gazette are partial and subjective, Spurrier was an influential and respected figure. His lack of interest in the Post Office building perhaps reflected wider opinions.

After the Post Office, Sinclair continued to experiment but rarely explicitly engaged with the classical style. Over the next twenty years, his designs included forms such as the Moorish horseshoe arch, blending superficially 'Islamic' styles with those with a longer history on the coast. His design for the National Bank of India again incorporated a classical balustrade, on the back wall. As Dean Sinclair notes, this was the same as on the Post Office, adding 'a measure of architectural cohesiveness to Sinclair's work'. ${ }^{35}$ This was the only classical feature on the Bank of India, which combined ogee arches and a hexagonal turret replete with arrowslits. Sinclair's individual patrons, who included the Sultan and a wealthy Indian merchant Mohamedbhai Sheikh Hoosenbhai, indicate that the local elite admired his works. Not all shared his vision, however. The designs of P. W. Harris, the Government Architect employed in the 1920s, reflected a plainer 'Arab' style, about which he published an article on its origins in Zanzibar. ${ }^{36}$ Harris was forced to redesign elements of Sinclair's final and most monumental building - the Peace Memorial Museum - after it collapsed during construction. ${ }^{37}$ Harris's article in the Journal of the Royal Institute of British Architects indicates that he did not share Sinclair's enthusiasm for eclecticism in architecture.

It is worth briefly mentioning the Peace Memorial Museum, as museums, like other municipal structures, were in the early nineteenth century built in Britain in classical

\footnotetext{
${ }^{34}$ For an image of the original stonework, see: https://www.flickr.com/photos/nationalarchives/5404881721/in/ album-72157625849814041/ accessed 1 November 2015.

${ }^{35}$ Dean Sinclair, "'Memorials More Enduring than Bronze': J.H. Sinclair and the Making of Zanzibar Town”, African Geographical Review 28 (December 2009): 71-97, p. 88.

${ }^{36}$ P. W. Harris, Journal of the Royal Institute of British Architects (1925): 341-5.

${ }^{37}$ Longair, Cracks in the Dome, p. 92-95.
} 
form, associating them with the earliest institutions in the Greek world for the study of the muses and with the fundamental purpose of the museum: to order and classify objects and cultures. Smirke's British Museum (completed 1852) established a model, and museums were built in classical form across Britain and the United States. The British Museum (Natural History) was one of the first to move away from the classical form in the $1870 \mathrm{~s}$ although its quasi-Romanesque style, creating a 'cathedral of science', was the subject of much debate. ${ }^{38}$ The role of the museum in the colony, however, could be interpreted differently. It is notable that in India museums were regarded as exceptionally suited to an Indo-Saracenic architectural style. ${ }^{39}$ The British architects of the National Gallery of Art in Chennai (1906) and the Prince of Wales Museum in Mumbai (1914) both created Indo-Saracenic designs, responding to the belief that this style was deemed appropriate for colonial educational institutions. In keeping with the early twentieth-century revival of the classical in India, the Victoria Memorial in Kolkata - a project driven forward by Lord Curzon - was 'the first major classically styled monument in India in half a century'. ${ }^{40}$ In Zanzibar, however, Sinclair executed a fully eclectic design which met the long-held desire by the British for greater animation of the cityscape, with its striking imposing dome and ornamentation largely inspired by Byzantine, Arabian and Indian Islamic architecture. The collapse and redesign, reducing its height significantly, reminds us of the compromises involved in such projects. In the event, Sinclair's ambitious and grandiose scheme created a fascinating and unusual building, but one which, with its hexagonal design, was not ideally suited for a museum. The global history which the museum would display - that of an Indian Ocean archipelago with historic links to South Asia, Arabia and Africa - was reflected within this design, in spite of the alterations imposed by the building process.

\section{Sinclair in Nairobi}

The final building to be considered here is the commission that Sinclair received from Lucie McMillan, widow of Sir William Northrup McMillan, for a new library in Nairobi to be built in his memory (Figure 4). This serves as an illuminating contrast with Sinclair's work in Zanzibar when considering the varied way in which these urban spaces had developed under colonial rule. The differences were vast. Nairobi was a city rapidly developed from a camp set up to build the Uganda Railway to a colonial capital within less than three decades. Responding to the demands of building the railway, infrastructure quickly grew up. Although space seemed apparently limitless in this area of the East African highlands, the marshy and undulating land imposed limitations. A fire in the 1900 s led to the rebuilding of much of the growing town. ${ }^{41}$ A formal town plan was not commissioned until 1926, but by that stage the town had developed on a grid plan with the various communities - British, Indian and Kenyan - living in segregated communities (ibid). An article in the East African

\footnotetext{
${ }^{38}$ Susan Sheets-Pyenson, Cathedrals of Science: The Development of Colonial Natural History Museums During the Late Nineteenth Century (Kingston: McGill-Queen's University Press, 1988).

Carla Yanni, Nature's Museums: Victorian Science and the Architecture of Display (London: Athlone, 1999).

${ }^{39}$ Metcalf, An Imperial Vision, p.96

${ }^{40}$ Ibid, p. 199.

${ }^{41}$ Maurice N. Amutabi, Buildings as Symbols and Metaphors of Colonial Hegemony: Interrogating Colonial Buildings and Architecture in Kenya's Urban Spaces. In Colonial Architecture and Urbanism in Africa: Intertwined and Contested

Histories, edited by Fassil Demissie, 325-46 (Farnham, Surrey: Ashgate, 2012) p.328.
} 
Standard bemoaned the inconsistency of style in Nairobi, noting that it had been described "not without adequate justification, as "a builder's back yard" (East African Standard, March 31, 1928, 11).

This writer reaffirmed the importance of architecture as a means for engendering 'proper civic pride' but warned that the scope of possibilities in Kenya demanded caution by local government in spending public funds 'on ornate architecture'. It is clear from various commissions (including that of Herbert Baker to be discussed below) that movements in the late 1920 s hoped to rationalise the cityscape and give a sense of uniformity.

American by birth, William Northrup McMillan was an early settler in the then British East Africa Protectorate, arriving in the mid-1900s with large sums of inherited wealth, a physically huge man with a reputedly forceful character. He became a significant landowner and member of Kenyan society, and was elected in 1920 to join the first Legislative Council. After his death in 1925, Lady McMillan offered to build a library in his memory. The East African Standard of 9 July 1927 explained the problems that Lady McMillan encountered with the Municipal Authorities about the location of the library she wished to erect (KNA, BN/1/43:2). She had the support of the Town Council and was ready 'to erect a handsome building at once' (ibid). Finally, in December 1927 the Governor in Council approved the plan.

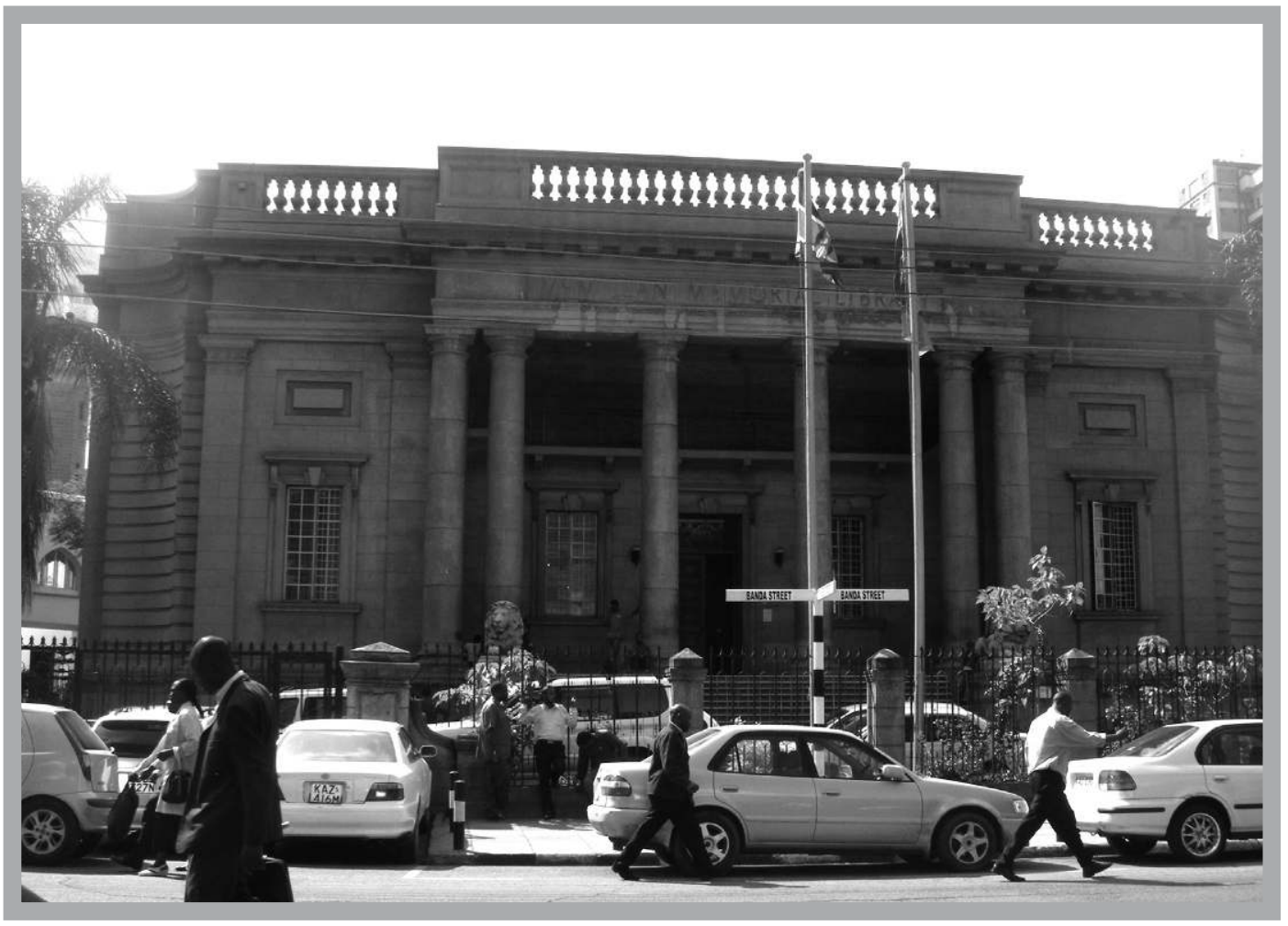

Fig 4. McMillan Library, Nairobi, completed 1931, designed by John Sinclair and Messrs. Rand Overy and Blackburn. Photograph: S. Longair. 
The Acting Commissioner for Lands made clear to the Colonial Secretary in London that Lady McMillan wished to restrict the library to Europeans only (KNA, BN/1/43:10). Discussions over this matter were discussed in earnest at a Finance Committee meeting related in the East African Standard of 24 May 1928 (KNA, BN/1/43 : 44). Lady McMillan agreed to pay for all costs except for the ongoing salary of a librarian and repairs to the building. Councillor De Souza objected to this use of municipal funding as only one part of the community would be permitted to use the building, while all sections contributed to these funds. In spite of explaining that he would have objected similarly had this been an Indian library, De Souza was accused of inciting racial tensions and his objections were defeated. The library finally opened in June 1931. It was given responsibility for distribution of books to public rural libraries across Kenya, which the East African Standard was at pains to explain was a scheme 'to benefit the whole colony' (KNA, BN/1/43:82).

Sinclair's memoirs do not, once again, include many details of this commission. He records that whilst on his second hunting safari early in his career in 1897, his party pitched tents on Ol Donyo Sabuk, a mountain in Thika, in central Kenya. The McMillans are both buried on the side of this mountain near their former home, known as McMillan Castle, built c. 1905. Sinclair recalled that this land 'was long afterwards bought by Sir Northrup Macmillan [sic], in whose memory, the Macmillan [sic] Memorial Library with the designing of which I had a good deal to do in 1924, was erected by his widow'. ${ }^{42}$ It is likely that this is an error of memory as McMillan died in 1925. Later in his memoirs, Sinclair described his activities on his return to England in 1923 after resigning as British Resident of Zanzibar. He reported being busy until 1926, with 'sporting activities, making gardens and tennis courts, designing houses and making plans for the Macmillan Memorial Library at Nairobi' ${ }^{43}$ In the memoir narrative, Sinclair's attention shifted at this point to the decision of him and his wife to visit Tangier for the winter months and eventually to move there permanently in 1930. On the opening of the library in 1931, the East African Standard reported the speech delivered by Lord Delamere, one of McMillan's fellow early settlers. In his oration, Delamere credited the architects Messrs. Rand Overy and Blackburn but noted that: 'We and they were fortunate in receiving the assistance and suggestions of Mr. J. H. Sinclair, C.M.G., the late Resident of Zanzibar whose artistic architectural works are well known to all East Africans' (East African Standard, 20 June 1931:30). It is possible, therefore, that he was influential in the early stages but that the Nairobi firm took over the construction and finished the project.

Sinclair had seen the development of Nairobi since the early 1900s. During a visit in 1904, friends there tried to persuade him to buy land in the growing town. His decision to decline this suggestion caused him to note ruefully: 'I could not take the risk and so missed the opportunity of becoming a millionaire'. ${ }^{44}$ Over the years in his various posts in Zanzibar he witnessed the town's rapid growth and, as one with architectural training, observed the dominant use of neo-classical styles in its new buildings. The new Governor, Sir Edward

${ }^{42}$ Senex Africanus, p. 50. 
Grigg, invited Herbert Baker to design the new Government House in Nairobi, and regional government buildings and schools across Kenya. In the early twentieth century, Baker was one of the most influential architects of empire, with major public buildings in South Africa and India. Metcalf credits Baker with reinvigorating the classical for the twentieth century empire, expressing 'ideals of law, order, and government that were in no way intended for South Africa alone'. ${ }^{45}$ Baker was insistent, however, that the classical be adapted to the environment and respond to local cultural heritage. Jan Hoogterp, with whom he had worked with South Africa, led the Kenyan projects, working within and developing Baker's classical idiom. It is worth noting that that Eric Dutton was at this time Grigg's personal secretary, and worked closely with Baker on the Nairobi Government House project. ${ }^{46}$ Later, as Chief Secretary in Zanzibar (1942-52), he and Ajit Singh Hoogan became the dominant architectural voices in Zanzibar and both brought their experiences from across East Africa to bear upon new developments for the urban landscape. ${ }^{47}$

Sinclair was likely to be more familiar with architecture within the British Empire than directly of emerging trends in Britain itself. In the early 1920s, Sinclair worked alongside Henry Vaughan Lanchester, then in Zanzibar to create a new town plan for the city. ${ }^{48}$ Lanchester was an experienced architect who had been closely involved with Edwin Lutyens's plan for New Delhi but also with the long-term construction of the Maharaja of Jodhpur's new palace. ${ }^{49}$ It is likely that Lanchester and Sinclair discussed architectural matters, particularly as Lanchester assisted with re-designing the Peace Memorial Museum after its collapse (ZNA, AB 41: Despatch from Resident to High Commissioner, 22 February 1923). Sinclair was therefore exposed both to the 'new colonial classicism' of New Delhi, which may have influenced his work for Nairobi.

The new library design maintains the classical style, in keeping with Baker's new Government House, which opened in 1928 and with Hoogterp's new Coryndon Memorial Museum, which opened in 1930. It was constructed of Nairobi bluestone according to architect Musau Kimeu, an excellent local building material. ${ }^{50}$ In a U-shaped plan, the library consists of a two-storey main block with single-storey wings extending back at either side. This simple formal plan is well-suited to a library, representing a significant contrast with Sinclair's decision to use a hexagonal design for the museum in Zanzibar. Its façade comprises a central Doric portico with double columns at each end, without a pediment. The name of the building is carved into the frieze and the whole is surmounted by a balustrade. Notable features which give the façade a less austere impression are its inwardly-curved corners, resembling those on the upper stories of Baker's contemporaneous

\footnotetext{
${ }^{45}$ Metcalf, An Imperial Vision, p. 247.

${ }^{46}$ Myers, Verandahs of Power, pp. 48-49.

${ }^{47}$ Ibid.

${ }^{48}$ William C Bissell, Urban Design, Chaos, and Colonial Power in Zanzibar (Bloomington IN: Indiana University Press, 2010).Sinclair, Memorials more Enduring than Bronze, pp. 91-93.

${ }^{49}$ David A. Johnson, New Delhi: The Last Imperial City (Basingstoke: Palgrave Macmillan, 2015 p.138-140.)

${ }^{50}$ Rupi Mangat, Slow death of Library that McMillan built, accessed October 15, 2015, http://www.theeastafrican.co.ke/ magazine/Slow-death-of-library-that-McMillan-built/-/434746/910652/-/item/1/-/624qhp/-/index.html

According to Rupi Mangat, "Slow death of Library that McMillan built", this stone is still in good condition, unlike the interior which is reportedly badly in need of repair.
} 
Bank of England. Like that building in London, the corners have banded rustication up to roof level. Another unusual inclusion is the balcony above the entrance within the portico, which perhaps provides some airflow to the first floor. Steps lead up to the library with two large lion sculptures on each side, instilling a sense of grandeur and perhaps also referring to McMillan's enthusiasm for game-hunting.

Although including some original features, such as the balcony within the portico, Sinclair's embrace of the classical form suggests he was not indiscriminately wedded to the eclectic style for which he was renowned in Zanzibar.

\section{Concluding Remarks}

Unlike Zanzibar, Nairobi was a new colonial city - constructed out of a railway camp during the construction of the Uganda Railway. It was from its inception a global city home to Kenyans, European settlers and Indian indentured labourers. From the typically haphazard buildings of its early years, the classical came to dominate, and buildings in this style benefited from heightened architectural expertise through the influence of Baker and Hoogterp. The McMillan library was therefore part of this movement of refinement, rationalisation and ordering of the city.

In considering the classical as 'global', the references for the British and Indian communities were imperial - as much to India and South Africa as to Britain, and even more distantly Greece and Rome. By way of symbolising the complex nature of Nairobi's urban space, the Jamia Mosque - one of the most monumental in Nairobi - is located next door, on an angle towards Mecca. This magnificent building disrupts the grid structure of the city and demonstrates the range of global influences which impinge upon the cityscape.

There was an alternative vision of the global produced by Sinclair in early colonial Zanzibar, one which reflected its historic links to societies around the Indian Ocean. Sinclair took the pre-existing architecture into account as well as the limitations imposed by the complex, labyrinthine city-plan and the climate. In this historically multicultural city, Sinclair used the classical rarely but freely, reflecting his authority - in spite of his limited training - over the British architectural vision with the liberty to experiment, as he did with the Post Office. I have used the extant buildings of a single administrator-architect to illuminate forms of architectural engagement by the British in East Africa - in particular in their response to the pre-existing hybrid landscape in Zanzibar, upon which Sinclair made the first significant British marks. His selective deployment of the classical, that most typical of British imperial styles, serves to demonstrate how the diversity of East Africa and the colonies' distinctive global connections demanded myriad responses from British architects. 


\section{Bibliography}

Amutabi, Maurice N. Buildings as Symbols and Metaphors of Colonial Hegemony: Interrogating Colonial Buildings and Architecture in Kenya's Urban Spaces. In Colonial Architecture and Urbanism in Africa: Intertwined and Contested Histories, ed. by Fassil Demissie, 325-46. Farnham, Surrey: Ashgate, 2012. "Archnet.org”, accessed November 2, 2015, http://archnet.org/sites/6953/media_contents/78746

Berg, Maxine. (ed.), Writing the History of the Global: Challenges for the 21st Century. Oxford: Oxford University Press for The British Academy, 2013.

Bissell, William. Casting a Long Shadow: Colonial Categories, Cultural Identities and Cosmopolitan Spaces in Globalizing Africa. In Postcolonial African Cities: Imperial Legacies and Postcolonial Predicaments, ed. Fassil Demissie: 25-41. London: Routledge, 2007.

Bissell, William C. Urban Design, Chaos, and Colonial Power in Zanzibar. Bloomington IN: Indiana University Press, 2010.

Bocchetti, Carla. Neoclassical Pompai in Early Twentieth-Century Cartagena de Indias Colombia. In Buen Gusto and Classicism in the Visual Cultures of Latin America, 17801910, (eds.), Paul B. Niell and Stacie G. Widdifield: 72-90. Albuquerque, NM: University of New Mexico Press, 2013.

“Antiquity and Global History.” Unpublished paper, IFRA, Nairobi, 2015.

Bremner, G. Alex. "Nation and Empire in the Government Architecture of Mid-Victorian London: The Foreign and India Office Reconsidered". The Historical Journal 48, no. 3 (2005): 703-42.

Imperial Gothic: Religious Architecture and High Anglican Culture in the British Empire, C. 1840-70. New Haven: Yale University Press, 2013.

Burton, Richard Francis. Zanzibar: City, Island and Coast. London: Tinsley Bros, 1872.

Ching, Francis D. K., Jarzombek Marc M. and Pakrash Vikramaditya. A Global History of Architecture. John Wiley \& Sons, 2011.

Crinson, Mark. Empire Building: Orientalism and Victorian Architecture. London: Routledge, 1996.

Crook, J. Mordaunt. The Dilemma of Style: Architectural Ideas from the Picturesque to the Post-Modern. London: John Murray, 1989.

Demissie, Fassil. Imperial Legacies and Postcolonial Predicaments: An Introduction. In Postcolonial African Cities: Imperial Legacies and Postcolonial Predicaments, ed. by Fassil Demissie: 1-10. London: Routledge, 2007.

(ed.), Colonial Architecture and Urbanism in Africa: Intertwined and Contested Histories. Farnham, Surrey: Ashgate, 2012.

Harris, P.W. Journal of the Royal Institute of British Architects (1925): 341-5.

Johnson, David A. New Delhi: The Last Imperial City. Basingstoke: Palgrave Macmillan, 2015. 
Longair, Sarah. Cracks in the Dome: Fractured Histories of Empire in the Zanzibar Museum, 1897-1964. Farnham, Surrey: Ashgate, 2015.

Mangat, Rupi. Slow death of Library that McMillan built, accessed October 15, 2015, http://www.theeastafrican.co.ke/magazine/Slow-death-of-library-that-McMillanbuilt/-/434746/910652/-/item/1/-/624qhp/-/index.html

Metcalf, Thomas R. An Imperial Vision: Indian Architecture and Britain's Raj. London: Faber, 1989.

Meier, Prita. "Objects on the Edge: Swahili Coast Logics of Display". African Arts 42, no. 4 (Winter 2009): 8-23.

Morris, Jan. In Quest of the Imperial Style. In Architecture of the British Empire, ed. Jan Morris and Robert Fermor-Hesketh: 10-31. London: Weidenfeld and Nicolson, 1986.

Myers, Garth. Verandahs of Power: Colonialism and Space in Urban Africa. Syracuse, NY: Syracuse University Press, 2002.

Musée des arts décoratifs de l'Océan Indien. Neoclassicism in the European Colonies of the 18th \& 19th Centuries: International Symposium Proceedings. Réunion Island, 2011.http://madoi.re/attachments/evenements/actes-neoclassicisme/Proceedings\%20 of $\% 20$ the $\% 20$ Neoclassicism $\% 20$ symposium $\% 20$-\%20MADOI.pdf.

Pearce, F. B. Zanzibar: The Island Metropolis of Eastern Africa. London: T. Fisher Unwin, 1920.

Port, Michael. Imperial London: Civil Government Building in London 1850-1915. New Haven; London: Yale University Press, 1995.

Sheets-Pyenson, Susan. Cathedrals of Science: The Development of Colonial Natural History Museums During the Late Nineteenth Century. Kingston: McGill-Queen's University Press, 1988.

Sheriff, Abdul. Zanzibar Stone Town: An Architectural Exploration. Zanzibar: Gallery Publications, 2008.

Sinclair, Dean. "'Memorials More Enduring Than Bronze': J. H. Sinclair and the Making of Zanzibar Stone Town.” African Geographical Review 28 (December 2009): 71-97.

Sinclair, John Houston. 'Senex Africanus: Reminiscences of Early Days in England, Kenya, Zanzibar and Tangier', n.d. [c. 1955]. Cambridge University Library: Royal Commonwealth Society Library, RCMS 180.

Tavernor, Robert. Palladio and Palladianism. London: Thames and Hudson, 1991.

Wright, Gwendolyn. Tradition in the Service of Modernity: Architecture and Urbanism in French Colonial Policy, 1900 - 1930. In Tensions of Empire: Colonial Cultures in a Bourgeois World, ed. by Frederick Cooper and Ann Laura Stoler: 322-45. Berkeley, CA: University of California Press, 1997.

Yanni, Carla. Nature's Museums: Victorian Science and the Architecture of Display.

London: Athlone, 1999. 